\title{
PROBLEMS OF YACHT CHARTER COMPANIES IN POLAND
}

\section{ALEKSANDRA ŁAPKO}

Maritime University of Szczecin, POLAND

e-mail: a.lapko@am.szczecin.pl

\author{
RECEIVED \\ ACCEPTED \\ JEL \\ CLASSIFICATION
}

KEYWORDS

ABSTRACT

\author{
27 July 2017 \\ 15 December 2017 \\ L26, L83, M20
}

yacht charter companies, yacht charter market, nautical tourism, management

There are more and more people interested in nautical tourism in Poland the consequence of which is the growing demand for charter services. Their development is important for the Polish tourism economy, but, similarly to the other attractions related to sailing tourism, they are rarely the subject of scientific research. The main purpose of the article is to diagnose the basic problems faced by charterers operating in Poland. In addition, the aim was also to organize and enrich the available terminology relating to the operation of chartering companies in order to partially fill the existing gap in this area.

The first part of this article presents the specificity of charter services, basic concepts related to charter activity and the classification of charterers' companies.

Additionally it shows a list of major companies along with the characteristics of the areas they operate in.

The further part includes the diagnosis and discussion of the basic problems faced by these companies based on questionnaire survey conducted in May 2017 among experts - managers of charter companies. It was found that these problems result from the existing legislation, high competition, rising operating costs, poor infrastructure of yacht ports and the seasonality of nautical tourism. Therefore, these problems are difficult to be solved and can only be reduced by adopting a proper operating policy.

\section{Introduction}

The main purpose of the article is to present the specificity of the functioning of yacht charter companies in Poland and to identify and discuss the main problems faced by these companies.

The research is based on questionnaire survey among experts, documentation, literature and online resources analysis and observation. 
The subject discussed is crucial for the development of nautical tourism. Nevertheless, it is extremely rare in the Polish and foreign scientific literature. In Poland issues related to charter yachts are discussed by M. Nowacki (2013), focusing on factors of quality. In turn, L. Butowski (2010) mentions charter services as one of the criteria used to benchmark the waters for nautical tourism. In a similar context, the topic is addressed by Croatian scientists, including T. Luković $(2015,2012)$. P. Cavo, A. Mrcel, H. Baricević (2010) or M. Uran and D. Gračan (2005). In their works charter services are listed as one of the determinants of the development of nautical tourism. It should be noted that nautical tourism in Croatia is considered to be an important element of the maritime sector and the leading type of tourism. The largest share in Croatian nautical tourism revenues in 2015 belonged to charter and berth services. In total they generated about $68.9 \%$ of revenue, which is close to 70 million euros (mppi.hr). Moreover, A. Alcover, M. Alemany and M. Jacob (2011) refer to the importance of the charter market for the Spanish economy. There is, however, no scientific study on the specific nature of charter companies.

\section{Basic information on the functioning of charter companies in Poland}

Yacht charter means to hire it for a certain period of time in order to organize the cruise. In nautical tourism there are three types of charters: bareboat, skippered and crewed (Jennings, 2003). In the case of bareboat charter, the charterer hires only the yacht for a certain price. Skippered charter includes also a person with the appropriate license - a skipper. Crewed charter consists of hiring a boat with full crew - not only a skipper, but also a cook or officers operating sails and maneuvering.

Charter is one of the most popular ways to enjoy yacht cruising. It is estimated that as many as $75 \%$ of sailing yachts on the Croatian waters are chartered yachts (Gracan, Gregoric, Martinic, 2016). Spain also experiences increasing charter revenues (Payeras et.al., 2011). This is a solution that avoids the many costs associated with owning a yacht - in particular, the cost of its purchase, but also berth, insurance, preparation for the season, launch and slip, servicing and repair. In addition, it gives the possibility to choose the vessel that fits the water and the nature of the cruise. For example, for lakes with a large number of shoals a charterer may choose a keel yacht, and for the sea - a typical sea yacht with large draught but safe construction.

It is also very important for the cruise to be launched at any port, which sometimes determines sailing on given water and provides the most efficient use of time spent for resting. Yacht charter also allows choosing the vessel in terms of the number and skills of people taking part in the cruise.

Figure 1 shows the types of charter companies divided by different criteria. Certainly, the criteria may be multiplied and a few other types of businesses may be selected, e.g. their size, the number of employees, or the service areas (inland or sea). Moreover, unambiguous classification of a company and its assignment to a single group is usually not possible. Therefore, it should be noted that the presented classification is only indicative and does not exhaust all possibilities. In addition, the types of companies show a large variety within their own types. For example, private companies include large companies with several hundred yachts, as well as individual business operators with one yacht that is occasionally chartered to individuals (so-called individual charter).

As far as domestic charter companies are concerned, their location is usually determined by the presence of appropriate tourist attractions for sailing, i.e. water bodies with appropriate parameters and development. Hence, the regions with the biggest number of charter companies in Poland include: the Great Masurian Lakes, the Baltic Coast, the Vistula Lagoon and the Żuławy Loop and the Szczecin Lagoon Area. 


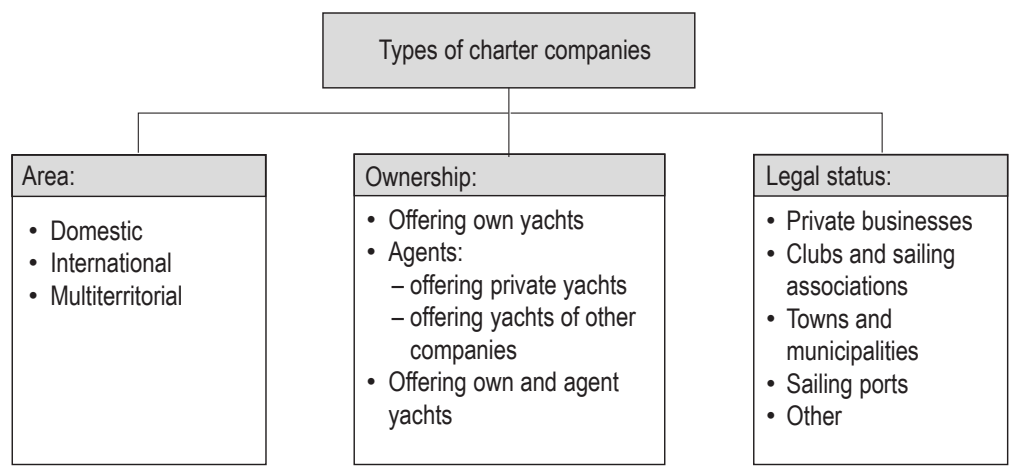

Figure 1. Types of yacht charter companies operating in the Polish market

Source: own study.

The number of yacht charter companies listed in the regions is presented in Table 1. However, the figures presented should be considered as indicative. There is no general database of this type of companies (except for the Great Masurian Lakes and the internet portal www.mazury.info.pl), so their number was established on the basis of research of online resources and specialized literature. Some of the operators offer charters in different regions and they have been presented in the table several times. The list includes companies that mainly offer sailing yachts. In the area of the Żuawy Loop and the Vistula Lagoon there are a lot of companies offering hiring of motor yachts and barges, which were not included in Table 1.

Table 1. Number of yacht charter companies in a given region

\begin{tabular}{lcccc}
\hline Region & Baltic Coast & $\begin{array}{c}\text { Żuławy Loop and the } \\
\text { Vistula Lagoon }\end{array}$ & Szczecin Lagoon Area & Great Masurian Lakes \\
\hline $\begin{array}{l}\text { Number of charter } \\
\text { companies }\end{array}$ & 48 & 11 & 15 & 106 \\
\hline
\end{tabular}

Source: own study based on online and trade literature resources.

As shown in Table 1, the biggest number of yacht charter companies are located in the area of the Great Masurian Lakes. In this region there are twice as much companies as those operating in the Baltic Coast region, although the entities from both the West Pomeranian and Pomeranian provinces were taken into account. It is worth mentioning that on 7 July 2017, when this research was conducted, more than 270 individual charters were also available in the Great Masurian Lakes region. The Great Masurian Lakes are still the most popular sailing destination in Poland. According to the report of the Polish Sailing Market, as many as $58 \%$ of Polish sailors declare to be cruising in this region (Raport: Polski rynek żeglarski, 2016). Estimates show that there are approximately 1200 yachts in the area offered for permanent hiring (Kulczyk, Derek, Woźniak, 2016).

The offer of existing companies is very diverse. The entities listed in Table 1 offer from 1 to over 100 vessels. The offered yachts vary in type, age, standard, equipment and size. The offer includes both long-term yachts for demanding customers as well as very luxurious vessels for tourists, who primarily focus on comfort. The advantage 
of the company is to have at its disposal at least several yachts of one type. This allows to organize regattas, where all participants have equal chances. These types of regattas are often indispensable elements of integration cruises organized for employees by different enterprises.

In Poland, companies offering charter services have to deal with seasonality. The sailing season lasts from the beginning of May to the end of October, which means that for half a year they cannot count on yacht hiring. The season itself is also characterized by fluctuations in demand. This is reflected in the calculation of charters rates. Typically, the season is divided into periods where the same vessel is subject to different rates. In the case of large professional companies there may be several periods like that (ahoj.pl, atsea.pl, balticayachts.pl, stratusczarter.eu). Smaller companies usually have two-three rate periods or offer yachts for a fixed rate (zagle.jmaster.pl, kliper.net. pl). The highest rates apply during the so-called long weekends, sailing events and in July.

Yachts are usually chartered for one week. Shorter charters usually mean the necessity to pay extra payment. To reduce the effects of the seasonality the companies offer a discount system by lowering prices on reservations made before the season - the so-called first minute reservations.

Unfortunately, the climate in Poland does not guarantee proper conditions for sailing even during the high season. Rain, low temperatures and strong winds can drastically reduce the number of people willing to cruise and are often a reason to cancel reservations. In such cases, the only revenue for charter companies are advance payments made on reservation.

\section{Problems related to running a yacht charter company in Poland - research results}

For the purpose of this article representatives of the 7 charter companies were interviewed with the use of the questionnaire. Five of the surveyed companies offered charters in the Great Masurian Lakes region, the other two in the Baltic Sea region. The number of yachts in the offer ranged from 3 to 50 . The companies have been operating in the market from 5 to 25 years.

Representatives of the companies participating in the interview were asked to indicate the basic problems they face every day. These problems included:

- high competition,

- increased operating costs,

- poor infrastructure of marinas,

- gray market,

- short periods of weather favorable to sailing,

- low level of sailors' skills.

High competition is a problem pointed out by all companies operating in the Great Masurian Lakes region. Company representatives believe that its cause is the easiness to obtain EU subsidies to finance the purchase of yachts. The wide range of charters available on the charter market forces them to set rates at a profit margin.

The operation of charter companies strongly depends on the existing yacht ports in the region - the scope and prices of their services and infrastructure. In recent years, many investment projects related to the modernization and construction of new yacht ports have been completed in Poland (e.g. the Żuławy Loop, West Pomerenian Sailing Route). Still, however, many facilities do not meet the growing demands of customers, and their poor equipment and poor quality of service make sailors choose other areas. 
Moreover, prices for port services translate directly into the operation of yacht charter companies. There is a lot of concern among the respondents in relation to the new Water Law Act prepared by the Ministry of the Environment. Under this law, port owners shall be taxed on land under water. After the protests of the sailing community, this tax is expected to be ten times lower than planned (zagle.se.pl). However, it may still cause them to raise prices for berths. This law will significantly reduce the attractiveness of nautical tourism in Poland. Changes to the existing regulations means that charter companies will be obliged to pay more for their fleet in the port and therefore lose the customers.

The problem for yacht charter companies is the phenomenon of the so-called gray market (Covo et.al, 2010). It is based on the fact that companies operating in the gray market pay no taxes but offer yachts to tourists at very low prices. Meanwhile, the price for many people is the basic criterion for choosing the company (Nowacki, 2013). In that case, offers of entities acting legally cannot be competitive. The operation of charter companies is also adversely affected by private yacht owners, who share their vessels with friends or strangers by charging them very little or even offering them for free.

Another problem for the functioning of charter companies is the climate in Poland and consequently a short sailing season. The uncertainty of the weather makes customers reluctant to charter yachts even though companies are trying to encourage customers to reserve them at lower prices for pre-season contracts. As the research shows, most often they make reservations in the months of May and June (39\%) - already in the season. About $20 \%$ of customers make reservations in March and April and only $7 \%$ in January and February. A lot of customers are waiting to make reservations until the last moment, when it is possible to predict the weather with high probability. Still, however, complaints reported by customers most often concern the weather conditions during the charter period $(66 \%)$.

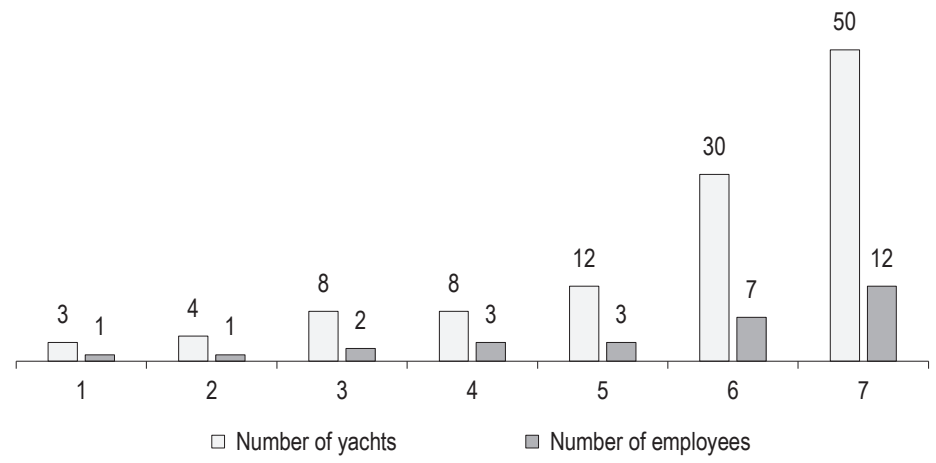

Figure 2. Relationship between the number of yachts owned and the number of employees in charter companies Source: own study.

The seasonality of charter services also forces seasonality of employment. Figure 2 shows the number of employees in each company and the number of yachts owned by them. According to the data presented, the companies employ on average one person per 3-4 yachts. In companies employing more than 2 employees an 
average of $2 / 3$ of the employees were employed in the high season. In a company employing 2 employees, only one person was employed on the basis of the contract for an indefinite time.

Seasonal employment provides the opportunity to reduce staff costs, but often generates problems in attracting people to work because they are usually employed based on mandate contracts (Echaust, 2009).

In addition to formalities (contract preparation, payment services), employees are required to hand over and receive yachts (equipment inspection, crew training), prepare the vessel (cleaning, repairs, retrofitting), transport crew to/from port. If the company offers crewed charter the staff duty is sometimes also to operate the vessel. The scope of duties is quite wide and the person is usually the only one representative of the company that the customer meets. Therefore, this person's attitude and skill translates itself into the satisfaction of the customer. Therefore, finding suitable employees can be a huge problem for companies.

The last problem indicated by the respondents is the low skill level of the sailors. This is largely due to the liberalization of regulations that has been taking place in recent years. According to the currently applicable sailing regulations (Rozporządzenie Ministra Sportu i Turystyki, 2013), yachts with length of up to $7.5 \mathrm{~m}$ can be used without license. These are large sailing yachts, many of which are used on Polish lakes that can take 4-6 sailors on board.

This regulation makes it possible for yachts to be hired by people without the proper skills to operate them. The short standard training provided by the charter companies when handing over the yacht does not replace the sailing course. Many yachts are damaged especially when the crew sails on shoals or during maneuvers in ports. Major breakdowns stop yachts from operating for repair and increase insurance rates, which adversely affects the company's income. In recent years, regulations regarding sailing standards and related skills have changed several times. High dynamics of changes in this area disorganized the functioning of companies conducting sailing trainings and also caused confusion among those who already had sailing licenses and had to exchange them. This was widely discussed among the sailors. Most likely, in the near future, no changes are to be applied in this area. Chartered companies can only introduce internal regulations, which may include entries that a sailing license is required regardless of the size of the yacht.

\section{Conclusions}

The purpose of the article was to diagnose problems faced by yacht chartering companies operating in Poland based on a questionnaire carried out among experts - persons running charter companies and market observation. On the basis of the answers received, it was found that the activity is hindered by high competition (often unfair, e.g. illegal charters) and increasing costs resulting, among others, from existing legislation. An additional difficulty is the high dependence on yacht ports. The poor condition of yacht port infrastructure in a given region makes sailors reluctant to visit those places, thus leading to little demand for charter services. The climate in Poland is also not conducive to charter activities. The season is short and even during the so-called high season, the weather is not always favorable to sailing. This entails the need to employ seasonal workers, which often affects the quality of their work. In addition, there is a high uncertainty of demand that hinders business planning. The last of these problems is the decline in the skills of sailors, which results from the progressive liberalization of the regulations.

Unfortunately, the nature of these problems makes it difficult to find solutions that can positively affect the functioning of charterers in Poland. Companies can introduce internal regulations that allow limiting damage caused by incompetent sailors, but this may be difficult due to the high competition visible on the charter services market. 
In order to maintain a proper position on the market, companies must ensure a high level of quality of services (good condition of yachts offered, a wide variety of offers, high level of customer service). However, it requires considerable financial outlay, and a high level of service additionally requires the training of personnel. This, in turn, hinders the high seasonality of nautical tourism and the resulting need to employ seasonal workers.

A positive phenomenon is the dynamic development of the yacht port infrastructure in Poland (e.g. Żuławy Loop, West Pomerenian Sailing Route), which contributes to the increase in the attractiveness of water bodies and causes an increase in the number of sailors, and thus the growing demand for charter services.

\section{Acknowledgments}

The results of the research were created within the framework of the research work entitled Badanie wybranych aspektów logistycznych turystyki żeglarskiej No. 9/S/IZT/2017 financed by subsidies from the Ministry of Science and Higher Education for the financing of statutory activities.

\section{Referenceres}

Alcover, A., Alemany, M., Jacob, M., Payeras, M., García, A., Martínez-Ribes, L. (2011). The economic impact of yacht charter tourism on the Balearic economy. Tourism Economics, 17 (3), 625-638.

Cavo, P., Mrcela, A., Baricević, H. (2010). "Crni Carter" u Republici Hrvatskoj. Pomorstvo Scientific Journal of Maritime Research, 24 (2), 147-164.

Echaust, M. (2009). Wybrane problemy zatrudnienia tymczasowego i sezonowego. Polityka Społeczna, 5-6, 15-19.

Gračan, D., Gregoric, M., Martinic, T. (2016). Nautical tourism in Croatia: current situation and outlook. Tourism \& Hospitality Industry, Congress Proceedings, 66-79.

Jennings, G. (2003). Marine tourism. Haworth Hospitality Press.

Kulczyk, S., Derek, M., Woźniak, E. (2016). Zagospodarowanie turystyczne strefy brzegowej jezior na potrzeby żeglarstwa - przykład wielkich jezior mazurskich. Prace i Studia Geograficzne, 61 (3), 27-49.

Luković, T. (2012). Nautical Tourism and Its Function in the Economic Development of Europe. In Visions for Global Tourism Industry. Retrieved from: https://www.intechopen.com/books/visions-for-global-tourism-industry-creating-and-sustaining-competitivestrategies/nautical-tourism-in-the-function-of-the-economic-development-of-europe (7.07.2017)

Luković, T., Gračan, D., Zec, D., Jugović, A., Petrinović, R., Serić, N., Milošević-Pujo, B., Asić, A., Horak, S., Gržetić, Z., Marušić, Z., Mader, B., Kundih, B., Morgan, P. (2015). Nautički Turizam Hrvatskie. Web Knižara.

Nowacki, M., (2013). Jakość w żeglarskiej turystyce czarterowej. In: W. Siwiński, R.D. Tauber, E. Mucha-Szajek (eds.), Aktualne badania naukowe $w$ dziedzinie turystyki, hotelarstwa i żywienia (pp. 345-356). Poznań: WSTiH

Payeras, M., Jacob, M., García, M.A., Alemany, M., Alcover, A., Martínez-Ribes, L. (2011). The Yachting Charter tourism SWOT: A basic analysis to design marketing strategies. Tourismos: An International Multidisciplinary Journal of Tourism, 6 (3), 111-134.

Raport: Polski rynek żeglarski. Retrieved from: http://warszawskisalonjachtowy.pl/wp-content/uploads/2017/06/Raport-do-pobraniaw-PDF.pdf (7.07.2017).

Rozporządzenie Ministra Sportu i Turystyki z dnia 9 kwietnia 2013 r. w sprawie uprawiania turystyki żeglarskiej, Dz.U. 2013, nr 0, poz. 460.

Uran, M., Gračan, D. (2005). The role of nautical tourism in the process of creating a Croatian competitive product (pp. 269-277). Proceedings of the 6th International Conference of the Faculty of Management Koper.

www.ahoj.pl (8.07.2017).

www.atsea.pl (8.07.2017).

www.balticayachts.pl (8.07.2017).

www.kliper.net.pl (8.07.2017).

www.mppi.hr (6.06.2016). 
www.stratusczarter.eu (8.07.2017).

www.zagle.jmaster.pl (8.07.2017).

www.zagle.se.pl (8.07.2017).

Cite this anticle as: Łapko, A. (2018). Problems of yacht charter companies in Poland. European Journal of Service Management, 1 (25), 165-172. DOI: 10.18276/ejsm.2018.25-20. 